\title{
Exploring Haidilao Service Creativity: The Perspective of Maslow's Hierarchy of Needs
}

\author{
Yan-hong LIU $^{1,2, a,{ }^{*}}$ and Xiao-wen $\mathrm{JIE}^{1}$ \\ ${ }^{1}$ Sichuan University, Business School, Chengdu 610064, China \\ ${ }^{2}$ Shenzhen University, Normal College, Shenzhen 518060, China \\ a841226273@qq.com
}

Keywords: Service Creativity, Hierarchy of Needs, Haidilao.

\begin{abstract}
Developing an understanding of relationship between employees and customers is of central importance to enterprise management. In this study we seek to find how service creativity made by Haidilao Hot Pot to its staffs, and then how service creativity made by Haidilao staffs to their customers in return. Following in depth interviews, content analysis, and combing with theory by Maslow's Hierarchy of Needs, We find that what Haidilao served for its employees with creativity at last had shifted all kinds of service creativities to customers. This study extends current knowledge of the shortsighted management of catering industry, and provides new perspective of treating employees. It provides a useful tool for restaurants human resource management. Furthermore, the result can serves as a reference for other Service-oriented businesses.
\end{abstract}

\section{Introduction}

China's catering industry has developed from extensive type to intensive and fine management, great changes have taken place in the demands of the market. With the continuous improvement of people's living standard, the transition of the social division of labor and consumption concept, the catering industry developed rapidly. But competition is so drastic that restaurants frequently go bankrupt. People's pursuit for daily food and beverage transfers from "do not have enough to eat" to "eat and be satisfied," from "eating well with taste satisfaction", gradually turned to "eating for fine service and atmosphere".

Haidilao Hotpot was founded by Zhang Yong with eight thousand RMB (about 1230 USD) in 1994 from Jianyang City, Sichuan Province. With swift development, it achieves more than 180 national chains, nearly twenty thousand employees and annual turnover of 5 billion RMB (about 0.77 billion USD). It becomes one of the Top 100 Chinese catering enterprises. Haidilao survived under the background of having neither enough customers nor enough money. It created its own advantages by practicing more, performing well with plenty of good ideas and creative designs. Not only to provide first-class service, but also to lead employees attentively launch creative services for customers.

\section{Enterprise Service Creativity for Employees}

Haidilao treats employees as his loved ones, building infinite love action under the management of limited system. Haidilao provides creative services for employees on the basis of the five levels of Maslow's demand theory. 


\section{Satisfy the Physiological Needs of Employees}

Haidilao employee compensation is relatively high compared with industry average wages. As the aspect of improving labor conditions, Haidilao arranges employees living within 20 minutes walking distance of departure in high-grade community, in order to let employees have good rest after work. In staff accommodation area, Haidilao has special cleaning aunt do housework clean affairs, cook delicious food and snack for employees. Employees will receive special care in case of illness, couples will enjoy a separate room. Employee's children can learn in Haidilao schools, employee's parents will receive bonus for employees' work outstanding.

\section{Meet the Safety Requirements of Employees}

Most of Haidilao staffs come from rural recruitment by introducing of friends and relatives. Haidilao offers salary and insurance for staff on time, formulates rules and regulations for the employees in a detailed and thoughtful way. Haidilao gets staff training tailor-made from the most basic safety knowledge to avoid employees distracted and confused about what to do for security issues.

\section{Satisfy Employees' Social Needs}

New employees can follow the teacher on post, ensure everything can find guidance. The new and old staffs care for each other. Whether internal staff and family members suffered serious illness, or encounter the threat from the outside, the manager and staffs are able to unite as one to find actively solutions. Timely communication between employees working experience to improve service quality and level has become classic Haidilao daily activities.

\section{Meet the Demand of the Respect of Employees}

Haidilao gives employees adequate space and appropriate authorization in promotion system and incentive policy. Haidilao staff members can upgrade from low to high along with the level of the floating salary. Haidilao offers financial rights to managers at all levels, even Haidilao attendants are authorized to give customers special discount or free of charge. All this authorization is based on trust between staff employees, fully supervise and constraints system of cheating being severely punished.

\section{Meet the Demand of Employees Self-fulfillment}

Haidilao calls on the workers to change their fates with both hands by hard working, motivates staff innovation service by material and spiritual double reward. Promote internal employees to management positions, form a happy management team, use high salary welfare and humanistic care to keep Haidilao independent cultivation management talent. The manager with fat salary can enjoy luxury chartered room, also can pursue further study in university at public expense. The series of policy make Haidilao the lowest staff turnover and the highest satisfaction in the catering industry, attract industry experts, professors' Haidilao investigation study at own expense. All of these inspire employees pride, enhance the cohesive affinity of Haidilao staffs. 


\section{Staff Service Creativity for Customer}

Haidilao staffs get enterprise's benefits and transfer their plain emotion into loyalty to the enterprise. Haidilao employees provide creative services for customers on the basis of the five levels of Maslow's demand theory.

\section{Satisfy Customer Physiological Needs}

Haidilao employees warmly welcome customers, concentrate on demands of every customer, and make them feel at home. Half of the order style is available in order to let customers taste several more kinds of dishes. If customers ordered too much, the dishes could be canceled immediately to avoid waste. Helpful employees serve different taste soft drinks for different customers, offer apron and mobile phone bag free of charge. They take good care of those who are old, weak, pregnant, children. Romance is made for those who are in love or every one's birthday, wedding ceremony, etc.

\section{Satisfy the Customer Security Requirements}

Haidilao staffs look for any chance of customers' safety requirements, create business opportunities. Haidilao launched hotpot takeaways and strictly trained staffs, provided hot pot of family services, create "HI to send" take-away brand during the SARS outbroke in China in 2003. Haidilao employees send hot pot door-to-door service, wear neatly tooling, bring their own shoe covers, help customers divide food, waiting for the customer outside and take away kitchenware and waste at last. "HI to send "continued to be very popular after the "SARS" and 9 kinds of soups were developed in market. In "soup blending" crisis, Haidilao faced customers sincerely, released the production process, opened kitchen for public to visit production line, won majority customers' trust and support. Haidilao daily food samples are displayed in the refrigerator in the customer waiting area, all this deepens the impression of customers that Haidilao's food is safe.

\section{Meet the Customers' Social Needs}

Haidilao sets up customer waiting area and makes it customer's social paradise and major factors of profit for the rate of turn table. The high satisfaction degree of customers comes from Haidilao's platform special made for different kinds of social demands. Haidilao provides free snacks, drinks, comfortable soft stools for the customer, and makes waiting area several parts which let customers feel enjoyable. Haidilao aims at fashionable women and respects women nature of loving beautiful as their social demand, creates for hands massage, manicure service, let women learn about how to care for themselves. As for children, parent-child paradise specially built to provide indoor children's amusement facilities let the children play together. As for old people, Haidilao employees not only chat with them, recommend their favorable dishes, but also hand in hand show them the way to restrooms, even offer back rubs massage.

\section{Meet the Demand of Customer Respect}

In order to respect customer, Haidilao employees put forward dozens of valuable, creative ideas to implement. In Haidilao's clean, fragrant restroom, staffs provide customers with comb, hairdryer, toothbrush, toothpaste, toothpicks, cups, hairdressing, cleanser, band-aid, charger, etc. Hope that through this little corner, let the customer go out with dignity. Respect for business customers, Haidilao not only offer free 
parking and parking service, but also provide them with special suites with video screen, allowing customers to improve work efficiency. For customers forget their departure time, Haidilao does not hesitate to send careless customers to the railway station by manager's SUV car. Haidilao parent-child botanical garden launches plant adoption services and encourages children to breed potted plants, promoting the public consciousness of environmental protection.

\section{Meet the Demand of Customer Self Actualization}

Haidilao uses i-pad as the dish order for customers to experience the advanced high-tech technology, colorful, varied, delicious dishes are presented for the customer simply with fingers' touch. Customers can systematically visit Haidilao waiting area, dining area and production area led by professional customer manager through appointment. Customers can see employees standardized operation and uniformed staff wearing white masks and caps. Posters shows work standards, procedures and employee promotion system. Hospitable staffs welcome customer with smile and courtesies. In the dining area, customers can watch performances of hand-pulled noodles and Sichuan opera face, experience the extensive and profound Chinese culture. Every customer in Haidilao feels himself as a God and accepts best wishes and services from Haidilao.

\section{Conclusions}

Haidilao continuously insists on service creativity, keeping pace with era, making staffs and customers grow up together. Haidilao has become successful Chinese business case of Harvard Business School in 2009 and has been highly respected in the business world. "Made in China" should refer not only product but also service. Haidilao best elaborates that service creativity brought market desire for the catering industry as well as faithful customer and rich profits for Haidilao. The competitive advantage based on Haidilao service creativity both in enterprises as employees for enterprises becomes the sustainable development case in cultural tourism service innovation. It provides a useful reference to improve the steady growth of economic and social benefits of enterprises effectively.

\section{Acknowledgement}

This research was financially supported by Guangdong Higher Education Teaching Reform Project Foundation.

\section{References}

[1] Xu Ya-ming, What does Haidilao scoop for? (in Chinese) China Railway Press, Beijing. 2016.

[2] Ding Ping, Build you team like Haidilao: Internal service class of Zhang Yong (in Chinese), The Wealth of China Publishing House, Beijing. 2015.

[3] Huang Tie-ying, You cannot master the skill of Haidilao (in Chinese), CITIC Publishing House, Beijing. 2011.

[4] Liu Xie-lin, Xu Xiao-dan, The Upgrading and innovation of catering industryTaking Haidilao as an example(in Chinese), Journal of Industrial Technological Economics. No.3 (2014): 3-13. 
[5] L.J. Cheng, J. Wang, Relationship among perceived quality, customer satisfaction and customer retention: An empirical research on Haidilao restaurant (in Chinese), Industrial Engineering Journal. No.5 (2013):125-132. 